\title{
Gully erosion susceptibility assessment by means of GIS-based logistic regression: A case of Sicily (Italy)
}

\author{
Christian Conoscenti ${ }^{a}$,, Silvia Angileri ${ }^{a}$, Chiara Cappadonia ${ }^{a}$, Edoardo Rotigliano ${ }^{a}$, \\ Valerio Agnesi ${ }^{\mathrm{a}}$, Michael Märker ${ }^{\mathrm{b}, \mathrm{c}}$ \\ a Department of Earth and Sea Sciences (DISTEM), University of Palermo, Via Archirafi 22, 90123 Palermo, Italy \\ b Department of Plant, Soil and Environmental Sciences, University of Florence, Piazzale delle Cascine 14, I-50144 Florence, Italy \\ ${ }^{c}$ Heidelberg Academy of Sciences and Humanities, c/o Department of Geography, University of Tübingen, Rümelinstr. 19-23, 72070 Tübingen, Germany
}

\section{A R T I C L E I N F O}

\section{Article history:}

Received 20 December 2011

Received in revised form 10 July 2013

Accepted 18 August 2013

Available online 29 August 2013

\section{Keywords:}

Gully erosion

Erosion susceptibility

GIS

Logistic regression

ROC curve

Sicily

\begin{abstract}
A B S T R A C T
This research aims at characterizing susceptibility conditions to gully erosion by means of GIS and multivariate statistical analysis. The study area is a $9.5 \mathrm{~km}^{2}$ river catchment in central-northern Sicily, where agriculture activities are limited by intense erosion. By means of field surveys and interpretation of aerial images, we prepared a digital map of the spatial distribution of 260 gullies in the study area. In addition, from available thematic maps, a $5 \mathrm{~m}$ cell size digital elevation model and field checks, we derived 27 environmental attributes that describe the variability of lithology, land use, topography and road position. These attributes were selected for their potential influence on erosion processes, while the dependent variable was given by presence or absence of gullies within two different types of mapping units: $5 \mathrm{~m}$ grid cells and slope units (average size $=2.66 \mathrm{ha}$ ). The functional relationships between gully occurrence and the controlling factors were obtained from forward stepwise logistic regression to calculate the probability to host a gully for each mapping unit. In order to train and test the predictive models, three calibration and three validation subsets, of both grid cells and slope units, were randomly selected. Results of validation, based on ROC (receiving operating characteristic) curves, attest for acceptable to excellent accuracies of the models, showing better predictive skill and more stable performance of the susceptibility model based on grid cells.
\end{abstract}

(c) 2013 Elsevier B.V. All rights reserved.

\section{Introduction}

Soil erosion by water is considered one of the major causes of land degradation in a wide range of environments (UNEP, 1994; Valentin et al., 2005; Zucca et al., 2006; Bou Kheir et al., 2007). In light of this, over the past decades, a large number of investigations have been carried out aiming at developing and testing methods for the evaluation of soil erosion processes. Most of these methods exploit an empirical or physically-based approach to quantitatively assess, at the plot scale, soil volumes eroded by rill and interrill processes. However, recent research (Poesen et al., 1996, 2002; Li et al., 2003; Valcárcel et al., 2003; Nyssen et al., 2008) highlighted that if the objective of a study is the assessment of water erosion on a drainage basin, the investigator has to also consider the contribution of gully erosion, which increases with the extension of the area, producing from $10 \%$ up to $94 \%$ of the total erosion (Poesen et al., 2003).

A gully is usually defined as a deep channel eroded by concentrated flow of water, removing upland soil and parent material, that is too big to be obliterated by normal tillage operations (USDA-SCS, 1966). Gullies are only intermittently occupied by water and are most likely to occur

\footnotetext{
* Corresponding author. Tel.: + 3909123864670 ; fax: + 390916169908.

E-mail address: christian.conoscenti@unipa.it (C. Conoscenti).
}

on unconsolidated slope deposits, weak shales and weathered soils (Imeson and Kwaad, 1980). They typically present a rectangular or V-shaped cross-section and a steep headcut which migrates upslope as a consequence of the erosion produced by overland flow, sub-surface piping and/or mass wasting processes (Bull and Kirkby, 1997; Kirkby and Bracken, 2009). A gully remains or grows when channel processes evacuate all material from upstream, any sediments eroded from head-cut and channel bottom, and material derived from the collapse of gully walls (Kirkby and Bracken, 2009). All the material can be delivered to river systems aggravating off-site effects of water erosion (Poesen et al., 2003).

In the 1980s, the term ephemeral gully was introduced to indicate smaller erosion channels scoured by concentrated overland flow that can be obliterated by normal tillage operations (Foster, 1986; Laflen et al., 1986). They are smaller than classical gullies but larger than rills. Unlike rills, ephemeral gullies recur in the same location each season and are strongly controlled by landscape configuration (Di Stefano and Ferro, 2011). Linear features of the landscape, where water flow concentrates, both natural (thalwegs of zero order basins or hollows) or anthropogenic (e.g. tractor tracks, parcel borders, access roads), may be suitable for hosting ephemeral gullies (Poesen, 1993). In the Mediterranean landscape, classical or permanent gullies usually develop in abandoned agricultural fields, rangelands or shrublands, while 
ephemeral gullies are typically found in cultivated fields, at least until they are erased by tillage operations (Poesen et al., 2002).

The size transition from rills to ephemeral gullies and then to classical gullies does not have clear limits. Even the boundary between a permanent gully and a river channel is very vague (Poesen et al., 2003). Imeson and Kwaad (1980) propose a minimum depth of $50 \mathrm{~cm}$ for classifying an erosion channel as a gully, although they admit the subjectivity of this criteria and state that a more clear distinction between rills and gullies can be made when considering their behaviour. Poesen (1993) separates (ephemeral) gullies from rills by a adopting a critical cross-sectional area of $929 \mathrm{~cm}^{2}$, a size threshold known as square foot criterion which was formerly used by Hauge (1977).

Gullies occur when a geomorphologic threshold is exceeded due to an increase in water flow erosivity and/or sediment erodibility (Patton and Schumm, 1975; Imeson and Kwaad, 1980; Poesen et al., 2003; Martínez-Casasnovas et al., 2004; Valentin et al., 2005; Zucca et al., 2006; Gómez Gutiérrez et al., 2011; Torri et al., 2012a). Environmental factors controlling critical conditions for gully development are mainly related to rainfall, topography, soil, lithology and land use. Rainfall temporal distribution influences runoff hydraulics and soil moisture: the former regulates flow erosivity while the latter before rainfall events influences both generation of runoff (Descroix et al., 2002; Castillo et al., 2003; Capra et al., 2012) and soil resistance to erosion (Bocco, 1991; Nachtergaele et al., 2002; Poesen et al., 2003; Torri et al., 2006; Bou Kheir et al., 2007; Magliulo, 2012; Torri et al., 2012b). Volume and velocity of concentrated flow are controlled by topographic attributes such as contributing drainage area, slope curvature and slope steepness (Moore et al., 1988; Vandekerckhove et al., 1998, 2000a; Poesen et al., 2003; Valentin et al., 2005; Zucca et al., 2006; Gómez Gutiérrez et al., 2009a, b; Kakembo et al., 2009; Nazari Samani et al., 2009; Capra et al., 2012; Svoray et al., 2012; Chaplot, 2013; Conoscenti et al., 2013). Depth and cross-sectional morphology of gullies are regulated by erodibility of soil horizons (Ireland et al., 1939; Imeson and Kwaad, 1980; Poesen et al., 2003) and characteristics of geological substrata (Vandekerckhove et al., 2000a; Zucca et al., 2006; Conoscenti et al., 2008; Conforti et al., 2010; Lucà et al., 2011; Marzolff et al., 2011; El Maaoui et al., 2012). Moreover, soil properties influence sub-surface flow and occurrence of piping phenomena, which can generate gullies when roofs of pipes collapse (Bocco, 1991; Bull and Kirkby, 1997; Bryan and Jones, 2000; Martínez-Casasnovas et al., 2004; Valentin et al., 2005; Pulice et al., 2012). Several studies have documented increases of gully erosion rates caused by land cover changes (Poesen et al., 2003 and references therein) and/or intensification of farming systems (Valentin et al., 2005 and references therein). In the Mediterranean landscape, expansion of pastures is often reported as one of the main drivers of gully erosion (Zucca et al., 2006; Gómez Gutiérrez et al., 2009b). The latter can also be enhanced by roads that intercept and concentrate overland flow, draining it on downstream slopes (Jungerius et al., 2002; Nyssen et al., 2002; Takken et al., 2008; Svoray and Markovitch, 2009).

In contrast to the significant contribution of gullies to total erosion on watersheds, which is particularly relevant in the Mediterranean region (Vandekerckhove et al., 1998, 2000b; Capra et al., 2012), few models have been developed for quantifying the effects of this phenomenon (Poesen et al., 2003). Among these are the following physically based models: CREAMS (chemicals, runoff and erosion from agricultural management systems; Knisel, 1980), EGEM (ephemeral gully erosion model; Merkel et al., 1988; Woodward, 1999), the method developed by Sidorchuk (1999) and the routine for linear erosion of the WEPP (water erosion prediction project; Flanagan and Nearing, 1995). These models, which require input parameters that are usually not available and/or difficult to assess, have rarely been thoroughly tested. In fact, the problematic nature of a physically based approach led the investigators to prefer simple empirical models for the evaluation of gully erosion. Recent articles reported that reliable estimations of ephemeral gully volumes can be simply obtained by assessing their lengths, while weak predictions are provided by the EGEM (Nachtergaele et al., 2001a, b; Capra et al., 2005). Further investigations confirmed that empirical relationships between eroded volume and channel length can be established for linear erosional landforms of different sizes including rills, ephemeral and permanent gullies, and badland channels (Bruno et al., 2008; Capra et al., 2009; Di Stefano and Ferro, 2011; KompaniZare et al., 2011; Caraballo-Arias et al., 2013; El Maaoui et al., 2012).

The above cited models do not predict spatial distribution of gullies, which is an important factor for planning erosion-control practices and for assessing the impact of environmental changes on the occurrence and location of gullies (Poesen et al., 2003). In this sense, an important contribution is given by several investigations focusing on the assessment of a topographic threshold that has to be exceeded for the initiation of a gully (Montgomery and Dietrich, 1992; Desmet et al., 1999; Kakembo et al., 2009; Nazari Samani et al., 2009; Svoray et al., 2012). Moreover, a suitable choice for predicting the location of gullies is the adoption of an inferential approach that allows an investigator to assess the spatial probability of gully occurrence within a given area, on the basis of statistical relationships established between environmental controlling variables and the spatial distribution of gullies. Hence, the calculated probability values can be used to generate maps of gully erosion susceptibility, showing how proneness to this phenomenon changes spatially. Different statistical methods have been recently adopted to predict spatial distribution of gully erosion on various spatial scales (see Table 1), from the field scale to the continental scale (Meyer and Martínez-Casasnovas, 1999; Hughes et al., 2001; Chaplot et al., 2005; Bou Kheir et al., 2007; Geissen et al., 2007; Conoscenti et al., 2008; Gómez Gutiérrez et al., 2009a; Conforti et al., 2010; Magliulo, 2010; Akgün and Türk, 2011; Lucà et al., 2011; Märker et al., 2011; Magliulo, 2012; Conoscenti et al., 2013).

The main objectives of this study are: i) analysing the environmental conditions determining the occurrence of gully erosion in the test area; ii) assessing the capability of logistic regression analyses to predict gully erosion susceptibility; iii) exploring the behaviour of the susceptibility models when trained and tested on different types of mapping units; and iv) evaluating the robustness of the predictive performance of the models when the learning and validation samples are altered. The experiment was carried out in a small basin of central-northern Sicily, which extends for $9.5 \mathrm{~km}^{2}$ and is affected by intense erosion. Logistic regression was selected as the multivariate statistical method for assessing gully erosion susceptibility because of the following reasons: i) it can work with a variety of types of independent variables such as categorical, binary, ordinal or continuous; ii) it is free of data distribution constraints (Bai et al., 2010); iii) it is also robust when input data

Table 1

Scale of the analysis, size of the study area and methods adopted in the studies cited, to predict the spatial distribution of gullies. CART: classification and regression trees; MARS: multivariate adaptive regression splines. average size of the 54 studied farms.

\begin{tabular}{llll}
\hline Article & Scale & Size & Methods \\
\hline Akgün and Türk (2011) & Regional & $424 \mathrm{~km}^{2}$ & Logistic regression \\
Bou Kheir et al. (2007) & Regional & $676 \mathrm{~km}^{2}$ & CART \\
Chaplot et al. (2005) & Catchment & $0.62 \mathrm{~km}^{2}$ & Linear regression \\
Conforti et al. (2010) & Catchment & $30 \mathrm{~km}^{2}$ & Information value \\
Conoscenti et al. (2008) & Catchment & $225 \mathrm{~km}^{2}$ & Conditional analysis \\
Conoscenti et al. (2013) & Catchment & $250 \mathrm{~km}^{2}$ & Conditional analysis \\
Geissen et al. (2007) & Regional & $3500 \mathrm{~km}^{2}$ & CART \\
Gómez Gutiérrez et al. & Farm & $26.4 \mathrm{ha}^{\mathrm{a}}$ & MARS \\
$\quad$ (2009a) & & & \\
Gómez Gutiérrez et al. (2009c) & Farm & $26.4 \mathrm{ha}^{\mathrm{a}}$ & MARS; CART \\
Hughes et al. (2001) & Continental & $1.7 \times 10^{6} \mathrm{~km}{ }^{2}$ & Gully density \\
Lucà et al. (2011) & Catchment & $30 \mathrm{~km}^{2}$ & Information value; \\
& & & logistic regression \\
Magliulo (2010, 2012) & Catchment & $10.5 \mathrm{~km}^{2}$ & Conditional analysis \\
Märker et al. (2011) & Catchment & $42 \mathrm{~km}^{2}$ & CART \\
Meyer and Martínez- & Vineyard & Not reported & Logistic regression \\
Casasnovas (1999) & parcel & & \\
\hline
\end{tabular}


are auto-correlated (Ohlmacher and Davis, 2003; Mathew et al., 2009), as often happens when dealing with environmental attributes; and iv) only a few studies have tested logistic regression for assessing gully erosion susceptibility (Meyer and Martínez-Casasnovas, 1999; Akgün and Türk, 2011; Lucà et al., 2011) and further investigations are needed.

\section{Materials and methods}

In this study, susceptibility to gully erosion was evaluated starting from the evidence of this phenomenon, i.e. the spatial distribution of gullies, following a principle widely adopted in geomorphology when reliable physical models are not available and processes are not well understood (Imeson and Kwaad, 1980).

In order to achieve the spatial variability of gully erosion susceptibility, a GIS database of gullies and controlling variables was generated. Hence, logistic regression analyses were carried out to obtain probability values of gully occurrence on two different types of mapping units for partitioning the study area: grid cells and slope units. The statistical modelling allowed us to define susceptibility conditions to gully erosion for the entire basin and generate susceptibility maps, by assigning to each mapping unit a value of probability to host a gully in the future. Validation procedures were adopted to evaluate the quality (i.e. reliability, robustness, degree of fitting and prediction skill) of the susceptibility models.

\subsection{Study area}

The study area is the watershed of the San Giorgio River. In terms of geological and geomorphological characteristics, this area can be considered representative of the Sicilian Apennines mainly underlain by clay deposits.

The basin is located in a mountainous sector of central-northern Sicily and extends for approximately $9.5 \mathrm{~km}^{2}$, ranging in elevation from 585 to $1020 \mathrm{~m}$ a.s.l. with an average of $770 \mathrm{~m}$ a.s.l. (Fig. 1). The landscape is smooth and rounded, as testified by a mean slope angle of $11^{\circ}$ with a standard deviation of $4.2^{\circ}$ (Fig. 2a). The climate of this sector of Sicily belongs to the Mediterranean type, characterized by wet and mild winter periods and hot and dry summers. Rainfalls, whose mean annual value is approximately $700 \mathrm{~mm}$, mainly concentrate in a few days in winter, while the summer period is characterized by almost drought conditions.
The area is characterized by wide outcropping of clay sediments, ranging from Upper Cretaceous to Lower Messinian in age, that occupy almost $90 \%$ of the total surface (Fig. $2 \mathrm{~b}$ ). These deposits give rise to gentle slopes, only interrupted by morphological steps, where less erodible rocks, given by conglomerates (Upper Tortonian-Lower Messinian), gypsum (Messinian) and sandstones (Lower Messinian), crop out.

The slopes of the basin are affected by shallow rotational or translational slides, earth flows and complex landslides, in addition to severe water erosion; the effects of the latter are particularly evident on clay outcroppings, where they cut some "calanchi" landforms (Phillips, 1998; Moretti and Rodolfi, 2000) and a number of gullies. These processes strongly affect the soils of the area, which are generally thin and weakly developed (mainly regosols and cambisols), with fine-medium texture (Fierotti, 1988).

Since agriculture activities occur in almost the entire area (see land use map of Fig. 2c), soil loss caused by water erosion results in a significant economic damage for the inhabitants. Moreover, the effects of soil loss on farmlands are also enhanced if the effective measures of erosion control by local farmers are lacking.

\subsection{Dependent and independent variables}

\subsubsection{Inventory of gullies}

The first step of the research was the mapping of the gullies in the San Giorgio River basin. The preparation of an inventory of landforms is a key step in geomorphological susceptibility mapping based on stochastic modelling. The analysis of high-resolution $(0.25 \mathrm{~m})$ orthophotos taken in 2007 and field surveys carried out in 2010 allowed us to map 260 gullies (Fig. 3a).

In the San Giorgio river basin, gullies are relatively small, with lengths from a few to ca. $500 \mathrm{~m}$ and a maximum depth of ca. $2 \mathrm{~m}$. Their cross-section is generally U-shaped although V-shaped channels can also be found (Fig. 3b-f), while their plan form is mostly linear (Ireland et al., 1939). Due to the shallow depth of soils, most of the gullies cut into the underlying bedrock.

Mapped gullies are mainly formed by concentrated runoff. However, subsurface flow plays a secondary role as suggested by the low frequency of piping. Gullies mainly occur on moderately steep slopes of valley sides, often starting at the middle slope portions, where overland flow concentrates. In most cases, gullies are connected to the river network, facilitating the evacuation of the material eroded from upland areas.
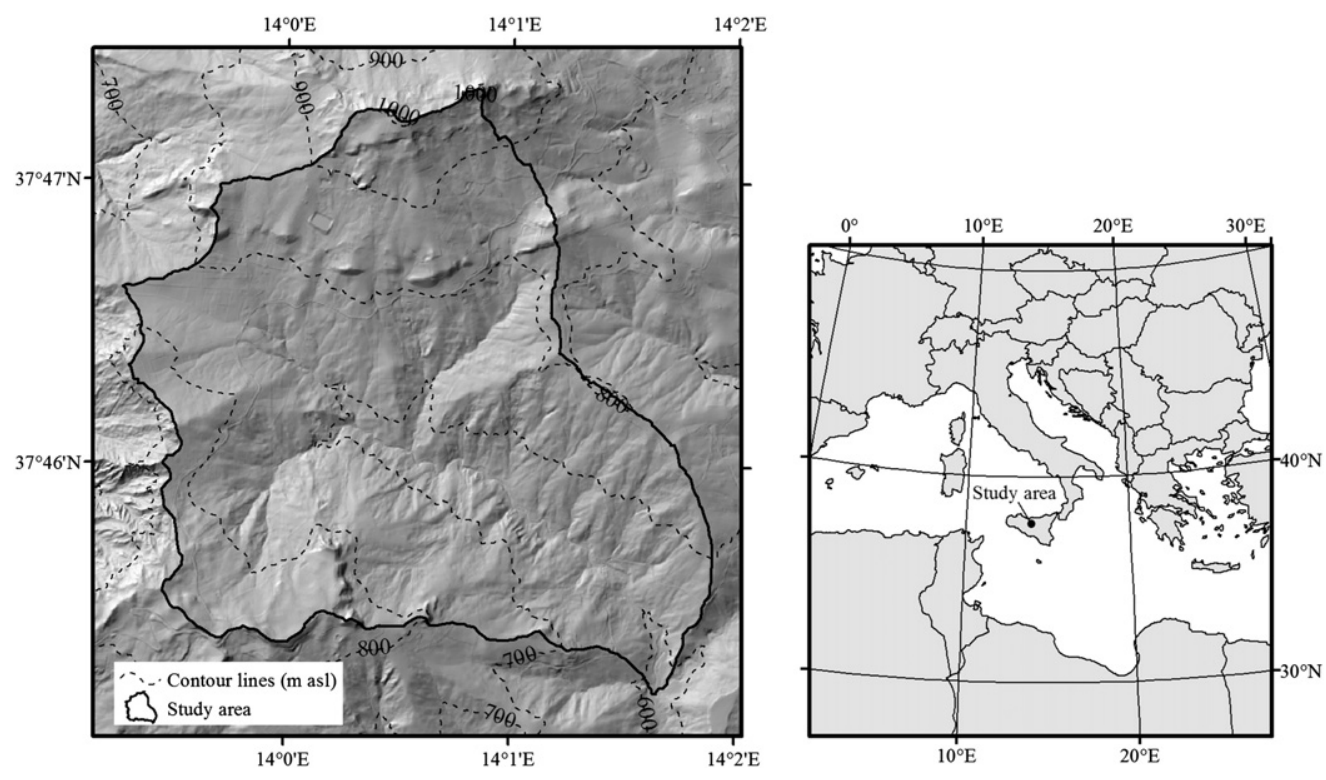

Fig. 1. Hillshaded DEM and location of the study area. 


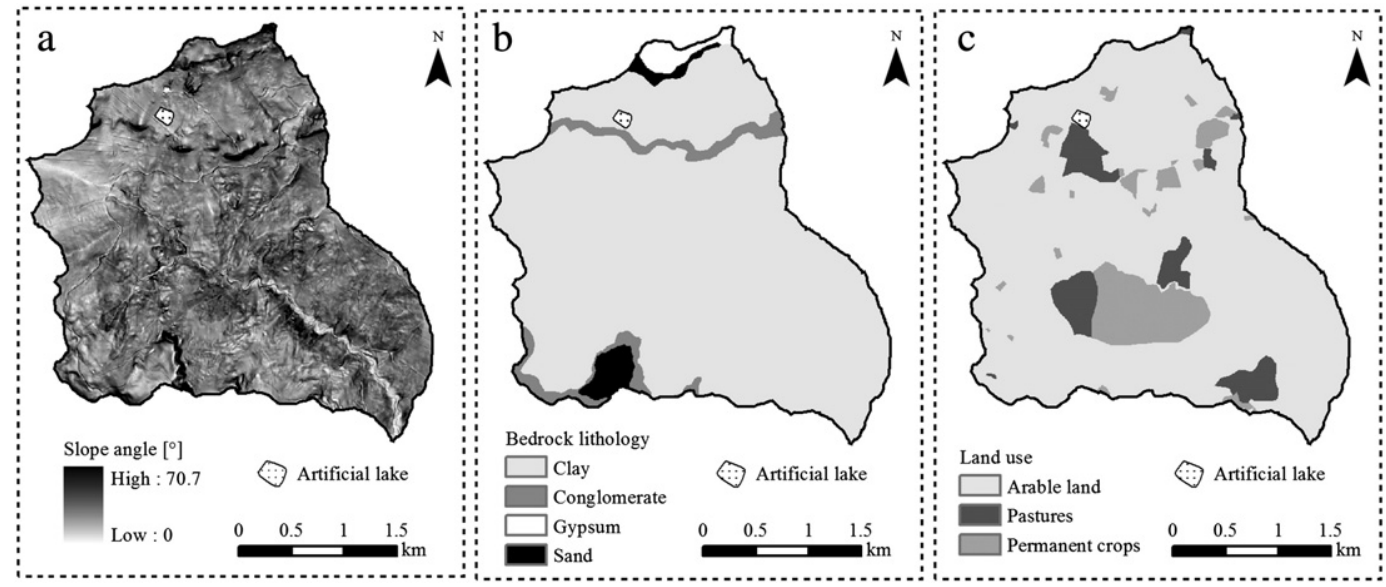

Fig. 2. Maps of slope angle (a), bedrock lithology (b) and land use (c).

Almost all gullies ( $98 \%$ of total gully length) are formed on slopes underlain by clay sediments. Sometimes gullies start close to the artificial drain outlets of roads, where runoff is concentrated and directed onto the downstream cultivated fields. Also unpaved access roads, tractor ruts and parcel borders, when downslope-oriented, are occasionally suitable for gully development. In addition, some gully head-cuts were observed on the depletion zones of shallow landslides, where sediments are poorly consolidated and concavity of topography favours concentration of runoff. Ephemeral gullies affecting cultivated parcels may be filled with sediments taken from adjacent areas and levelled by tillage operations, but they usually occur again in the same position during the following rainy season.

Once mapping of the gullies was completed, their spatial distribution was coded as presence or absence of landforms within the mapping units. This binary information was used as the dependent variable in the statistical analysis.

\subsubsection{Mapping units}

The selection of suitable mapping units is a key step in modelling the spatial occurrence of geomorphological processes and related landforms. A mapping unit is a portion of the landscape whose boundaries maximize internal homogeneity and between-units heterogeneity, in relation to a set of environmental conditions (Guzzetti et al., 1999). To these units, a value/class of each independent variable and a susceptibility level is assigned. Different types of mapping units have been proposed to partition the land surface for GIS analysis (Carrara et al., 1995; Baeza et al., 2009). Among these, the terrain mapping units are identified by analysing aerial photographs and field surveys, in a way that each unit

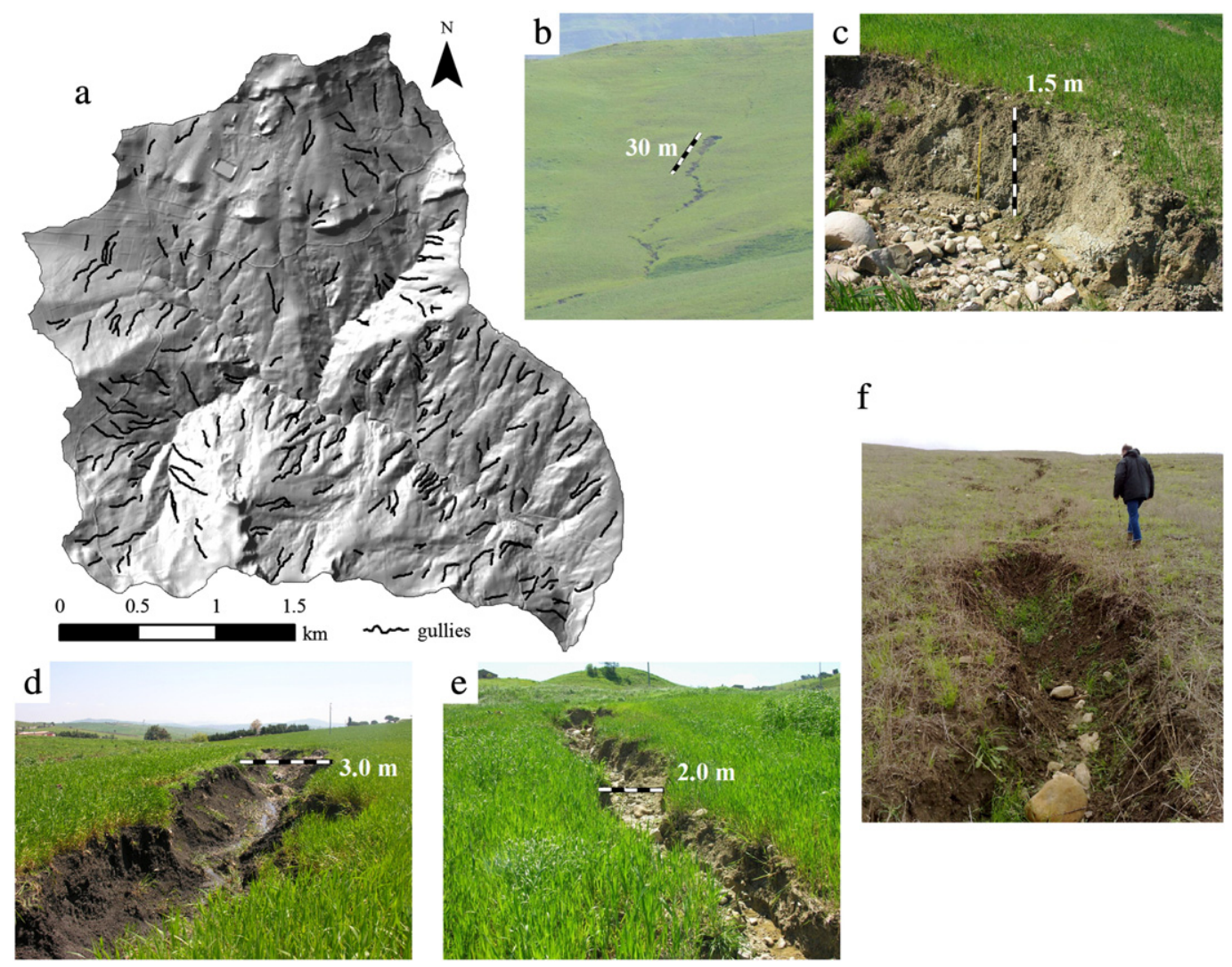

Fig. 3. Map of the observed gullies (a) and pictures of some of the mapped gullies (b-f). 
forms a unique association of lithology, soils and slope steepness (Meijerink, 1988). Another type, the slope units, represents hydrological regions between drainage and divide lines, automatically derived from high quality DEMs, which may correspond to a sub-basin or one of the left and right sides (Guzzetti et al., 1999). Such a method was adopted by Meyer and Martínez-Casasnovas (1999), who predicted the occurrence of gullies in vineyards of north-east Spain by using sub-basins as elementary sampling units. However, the increasing resolution of digital elevation models (DEMs), available at various scales, stimulated the investigators to adopt grid cells of the same size of the DEM pixels as mapping units for the spatial prediction of water erosion processes (see Bou Kheir et al., 2007; Conoscenti et al., 2008; Gómez Gutiérrez et al., 2009a,b; Conforti et al., 2010; Magliulo, 2010; Akgün and Türk, 2011; Lucà et al., 2011; Märker et al., 2011; Magliulo, 2012; Conoscenti et al., 2013). In this study, we analysed the susceptibility conditions to gully erosion by using, as mapping units, grid cell units (CLUs) and slope units (SLUs): the CLUs simply correspond to the $5 \times 5 \mathrm{~m}$ pixels of the DEM available for the investigated area. The SLUs were delimited by applying the ArcGIS 9.3 watershed function (ESRI, 2008); the outlet of each channel in the San Giorgio river network was used to derive sub-basins, and each basin was divided into two parts: the left and right sides. According to these two partitioning criteria, the study area was subdivided in 376,099 $5 \times 5 \mathrm{~m}$ CLUs and 353 SLUs, the latter having an average over 2.66 ha. The intention of exploiting the maximum possible resolution of topography led us to use the CLUs, while the SLUs were chosen in order to explore the behaviour of the susceptibility models in relation to the natural limits of overland flow.

\subsubsection{Controlling factors}

The CLUs and the SLUs covering the study area were assigned with the values of a set of environmental attributes, in addition to the binary response (i.e. presence or absence of a gully) of the dependent variable.
The explanatory variables were selected in order to reproduce the erodibility of outcropping materials, the erosivity of overland flow, the influence on erosion processes of topographic position and the effects of the river and road networks. Due to the small size of the study area, climatic conditions have been considered homogeneous and, as a consequence, no climatic attributes were used to build the predictive models.

The dataset of the predictor variables consists of 24 attributes defined for both the CLUs and SLUs (Table 2). For the CLUs, the values of the attributes were derived directly from the raster layers that were generated for each of the factors; for the SLUs, the environmental parameters were calculated by applying zonal statistics to the cells falling inside each mapping unit.

The effects of terrain erodibility conditions on the distribution of erosion phenomena were explored by analysing the spatial pattern of bedrock lithology, land use and slope aspect. While the first two attributes are widely recognized as having a direct control on water erosion, slope aspect could have a potential indirect effect, given its relation with vegetation distribution and geo-structural conditions. Bedrock lithology and land use were derived from a 1:50,000 geological map (Abate et al., 1988) and CORINE land cover 2000 (scale = 1:250,000), in addition to field surveys and analysis of the same orthophotos used to map the gullies; the compass direction of slope was automatically generated as a grid layer from the DEM, reclassifying its values in eight categorical intervals. For the statistical analysis, an explanatory variable was derived from each class of lithology, land use and aspect. For the CLUs, these variables were defined by binary values (i.e. 1 for cells where the class occurs, and 0 for cells where it does not), while the relative frequency of each class computed was assigned to each SLU.

The erosive power of runoff, in terms of potential discharge, flow velocity and transport capacity, was modelled by means of four primary topographic attributes (elevation range, slope angle, plan and profile curvature) and three secondary ones (stream power index, topographic

Table 2

Independent explanatory variables and methods adopted for their calculation. Mean and standard deviation values of continuous variables are shown.

\begin{tabular}{|c|c|c|c|c|c|c|c|}
\hline Independent variables & & & & & \multirow{2}{*}{$\begin{array}{l}\text { Cell units (CLUs) } \\
\text { Attribute values }\end{array}$} & \multicolumn{2}{|c|}{ Slope units (SLUs) } \\
\hline \multicolumn{4}{|l|}{ Categorical variables } & & & \multicolumn{2}{|c|}{ Attribute values } \\
\hline \multirow[t]{4}{*}{ Bedrock lithology } & \multicolumn{2}{|l|}{ Clay } & LTL_clay & & Binary response $[0,1]$ & \multicolumn{2}{|c|}{ Class relative frequency } \\
\hline & \multicolumn{2}{|l|}{ Conglomerate } & LTL_cong & & Binary response $[0,1]$ & \multicolumn{2}{|c|}{ Class relative frequency } \\
\hline & \multicolumn{2}{|l|}{ Gypsum } & LTL_gyps & & Binary response $[0,1]$ & \multirow{2}{*}{\multicolumn{2}{|c|}{$\begin{array}{l}\text { Class relative frequency } \\
\text { Class relative frequency }\end{array}$}} \\
\hline & Sandstone & & LTL_sand & & Binary response $[0,1]$ & & \\
\hline \multirow[t]{3}{*}{ Land use } & \multicolumn{2}{|l|}{ Arable lands } & USE_arab & & Binary response $[0,1]$ & \multicolumn{2}{|c|}{ Class relative frequency } \\
\hline & \multicolumn{2}{|l|}{ Permanent crops } & USE_crop & & Binary response $[0,1]$ & \multicolumn{2}{|c|}{ Class relative frequency } \\
\hline & \multicolumn{2}{|l|}{ Pastures } & USE_past & & Binary response $[0,1]$ & \multicolumn{2}{|c|}{ Class relative frequency } \\
\hline \multirow[t]{8}{*}{ Slope aspect } & \multicolumn{2}{|l|}{ North } & ASP_N & & Binary response $[0,1]$ & \multicolumn{2}{|c|}{ Class relative frequency } \\
\hline & \multicolumn{2}{|l|}{ North-East } & ASP_NE & & Binary response $[0,1]$ & Class & requency \\
\hline & East & & ASP_E & & Binary response $[0,1]$ & Class & requency \\
\hline & South-East & & ASP_SE & & Binary response $[0,1]$ & Class & requency \\
\hline & South & & ASP_S & & Binary response $[0,1]$ & Class & requency \\
\hline & South-West & & ASP_SW & & Binary response $[0,1]$ & Class & requency \\
\hline & West & & ASP_W & & Binary response $[0,1]$ & Class & requency \\
\hline & North-West & & ASP_NW & & Binary response $[0,1]$ & Class & requency \\
\hline Continuous variables & & Attribute v & & & Attribute values & & \\
\hline & & & Mean & Std.dev. & & Mean & Std.dev. \\
\hline Elevation [m asl] & ELE & Cell value & 767.7 & 78.3 & Mean value & 764.6 & 76.3 \\
\hline Elevation range [m asl] & ELR & - & - & - & range & 66.6 & 27.4 \\
\hline Slope angle $\left[{ }^{\circ}\right]$ & STP & Cell value & 11.09 & 4.65 & Mean value & 11.13 & 2.43 \\
\hline Plan curvature $\left[\mathrm{rad}^{-1}\right]$ & PLC & Cell value & -0.028 & 0.513 & Mean value & 0.007 & 0.062 \\
\hline Profile curvature [ $\left.\mathrm{rad}^{-1}\right]$ & PRC & Cell value & -0.064 & 0.547 & Mean value & 0.018 & 0.058 \\
\hline Stream power index [m] & SPI & Cell value & 1.005 & 1.260 & Mean value & 1.032 & 0.165 \\
\hline Topographic wetness index [m] & TWI & Cell value & 6.518 & 0.860 & Mean value & 6.556 & 0.261 \\
\hline Length-slope factor & LSF & Cell value & 2.301 & 5.036 & Mean value & 3.015 & 0.853 \\
\hline Topographic position index [m] & TPI & Cell value & -0.047 & 3.019 & Mean value & -0.146 & 0.860 \\
\hline Distance from roads [m] & DFR & Cell value & 115.0 & 92.1 & - & - & - \\
\hline Road network length [m] & RNL & - & - & - & Total road length & 89.9 & 127.9 \\
\hline $\begin{array}{l}\text { Flow distance } \\
\text { to river network }[\mathrm{m}]\end{array}$ & FDR & Cell value & 194.1 & 137.1 & Maximum value & 396.3 & 146.0 \\
\hline
\end{tabular}


wetness index, length-slope factor), which were all derived from the DEM; a morphodynamic interpretation of these attributes is given in Wilson and Gallant (2000).

In order to explore the influence of topographic position, both in absolute and relative terms, elevation and the topographic position index (TPI) were considered, respectively. TPI (Weiss, 2001) represents the erosion/accumulation capacity of terrain as it expresses a quantitative relation between the elevation of a cell and those of the surrounding cells; the index was computed for each cell by using the algorithm of Jenness (2006) and selecting a buffer of $100 \mathrm{~m}$ to identify the neighbouring cells.

The potential effects of road and river networks, derived from $1: 10,000$ scale topographic maps, on gully erosion were investigated for the CLUs, by calculating the distance from the closest road segment and the flow distance to the river network; the latter attribute (Fig. 4) was computed by using the module of SAGA GIS (Olaya, 2004) "overland flow distances to channel network" and selecting the algorithm "multiple flow direction". The total length of roads and the maximum value of flow distance to river network, calculated within each slope unit, were also considered as explanatory variables for the presence or absence of gullies.

\subsection{Logistic regression analysis and model accuracy evaluation}

Multivariate statistical analyses have been commonly adopted in recent years for mapping susceptibility to landslides and water erosion. Among these techniques, logistic regression analysis (cf. Hosmer and Lemeshow, 2000) is one of the most frequently used, since it allows us to generate reliable predictive models from explanatory variables of different types (either continuous or discrete) and not necessarily having normal distributions. Therefore it was selected as the multivariate statistical tool for mapping gully erosion susceptibility in the San Giorgio River basin.

Logistic regression evaluates the probability $(P)$ of an event occurrence by estimating the probability that a case will be classified into one of two mutually exclusive categories as opposed to the other category of the dependent dichotomous variable (Menard, 1995; Ohlmacher and
Davis, 2003). In this study the event occurrence is represented by the presence of gullies within a mapping unit and the logistic regression is exploited to predict a binary variable $(Y)$ that could be equal to 1 (presence of gully) or 0 (absence of gullies).

The algorithm of logistic regression applies the maximum likelihood technique to maximize the value of the log-likelihood $(L L)$ function, indicating the likelihood to obtain the observed values of $Y$, from the given values of the independent variables and coefficients (Menard, 1995). $L L$ multiplied by -2 , called negative log-likelihood, has approximately a $\chi^{2}$ distribution. It can be used to evaluate the fitting of a logistic regression model to the observed data: smaller $-2 L L$ values indicate a better fitting (Hosmer and Lemeshow, 2000). The difference between the value of $-2 L L$ computed for the model with only the intercept $\left(D_{0}\right)$ and that for the full model $\left(D_{\mathrm{M}}\right)$ can be used for a $\chi^{2}$ test of significance of the regression coefficients (Ohlmacher and Davis, 2003; Akgün and Türk, 2011); if the difference between $D_{0}$ and $D_{\mathrm{M}}$ is statistically significant ( $p \leq 0.05)$, a better prediction of $P(Y=1)$ is obtained for the independent variables (Menard, 1995).

In this study, logistic regression analyses were performed by means of the open source software TANAGRA (Rakotomalala, 2005), adopting a forward stepwise strategy to select the explanatory variables. For both types of considered mapping units, the first stage was the production in ArcGIS of a data matrix, where each row corresponds to an individual case (i.e. a single grid cell or slope unit) while columnar data show the values of the explanatory and response variables. In multivariate statistical analysis it is desired that predictor variables share the same scale (Nefeslioglu et al., 2008) and have the same range as the dependent variable (Ripley, 1996). Therefore, the selected environmental attributes were scaled between 0 and 1 .

Despite the relatively large number (260) of gullies that were recognized in the studied area, only $2.38 \%$ of the cell units host a gully; as a consequence, the 8949 grid cells mapped as "positive" provide a quite low ratio of gully presence (1)/gully absence (0), when compared to the total number $(376,099)$ of cells in the area. Since a balanced subdivision of positive and negative cases in the training dataset is generally recommended (Nefeslioglu et al., 2008; Bai et al., 2010), logistic regression analyses were performed by
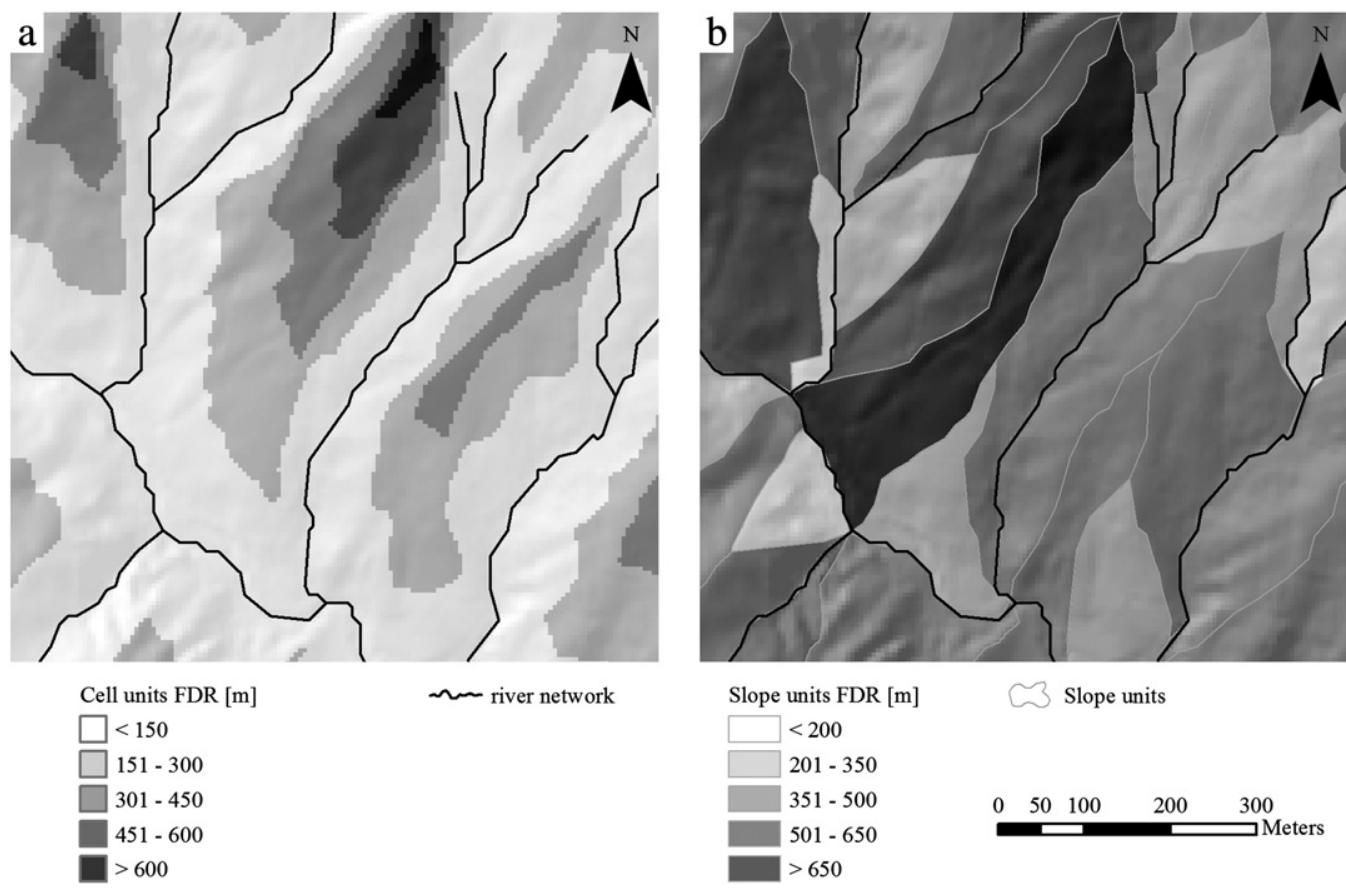

Fig. 4. GIS layer of the attribute "flow distance to river (FDR) network" generated for CLUs (a) and SLUs (b). 
selecting groups of training cells, balanced in terms of positive and negative cases. An equal distribution of presences and absences of gullies was also used as the criterion for picking up training subsets of slope units, even if, in this case, the presence/absence ratio from the entire basin is not so far from 1 (158/195).

Since the acceptance of a predictive model requires the evaluation of its robustness to small changes of the input data (i.e. data sensitivity), gully erosion susceptibility models were prepared on three different samples of mapping units for both CLUs and SLUs.

The learning subsets of CLUs were collected according to the following two steps: 1) selection of first three samples (A, B and C) of 17,898 cells, each given by all the positive cases ( 8949 cells) and the same number of negative cases randomly collected, maintaining a minimum distance of $25 \mathrm{~m}$ between each other and from positive pixels to reduce the effects of spatial auto-correlation; 2) random selection of 14,318 cells ( $80 \%$ of the first sample), equally distributed between positive and negative cases. The cells not selected in the second step (3580 for each of the first samples) were used to test the accuracy of the models. The adopted strategy provided three training samples $\left(\mathrm{A}_{\mathrm{cal}}, \mathrm{B}_{\mathrm{cal}}\right.$ and $\left.\mathrm{C}_{\mathrm{cal}}\right)$ and three test samples $\left(A_{v a l}, B_{v a l}\right.$ and $\left.C_{v a l}\right)$. By applying a stratified random selection strategy, imposing $50 \%$ of positive cases within the subset, the 353 SLUs were split into three calibration datasets $\left(D_{c a l}, E_{c a l}\right.$ and $\left.F_{c a l}\right)$ and three validation datasets $\left(D_{v a l}, E_{v a l}\right.$ and $\left.F_{v a l}\right)$, made up of 176 and 177 SLUs, respectively. Since the SLUs can be considered as individual morphodynamically independent case (Rotigliano et al., 2011,2012), the three training samples were collected without any spatial constraint.

By performing logistic regression analysis on the learning datasets, three gully erosion susceptibility models were obtained for each of the mapping unit types. The models fitting to the observed data was evaluated by computing the values of the Cox and Snell and Nagelkerke pseudo- $R^{2}$ in addition to the statistic $-2 L L$. The logistic regression component of the software TANAGRA also provides the results of the model chi-square test, which allows for assessing the global significance of the regression coefficients; the significance was also evaluated individually for each independent variable incorporated in the model by means of the Wald test.

The accuracy of logistic regression in modelling susceptibility to gully erosion was evaluated by drawing, for each model, the receiver operating characteristic (ROC) curves (Lasko et al., 2005) and by computing the values of the area under the ROC Curve (AUC; Hanley and McNeil, 1982). An ROC curve plots true positive rate TP (sensitivity) against false positive rate FP ( 1 - specificity) for all possible cut-off values; sensitivity is computed as the fraction of cells hosting gullies that were correctly classified as susceptible, while specificity is derived from the fraction of cells free of gullies that were correctly classified as not-susceptible. The closer the ROC curve to the upper left corner $(A U C=1)$, the higher the predictive performance of the model; a perfect discrimination between positive and negative cases produces an AUC value equal to 1 , while a value close to 0.5 indicates inaccuracy in the model (Fawcett, 2006; Akgün and Türk, 2011). In relation to the computed AUC value, Hosmer and Lemeshow (2000) classify a predictive performance as acceptable ( $A U C>0.7)$, excellent $(A U C>0.8)$ or outstanding $(A U C>0.9)$. ROC curves were drawn both for the validation (test) and calibration (training) datasets, in order to evaluate predictive performances of the models and to further investigate their fit to the training observations; moreover, the difference between apparent accuracy (on training data) and validated accuracy (on test data) indicates the amount of overfitting (Märker et al., 2011).

\section{Results}

\subsection{Cell unit (CLU) models}

The fit of the regression models with data observed from the training subsets of cells $\left(A_{\text {cal }}, B_{\text {cal }}\right.$ and $\left.C_{\text {cal }}\right)$ is quantitatively evaluated by the $-2 L L$ and pseudo- $R^{2}$ statistics, while the model chi-square test shows the global significance of the regression coefficients. The values of these parameters indicate a statistically significant fit of all the CLU models with their training area (Table 3). Since the results are quite similar for the three subsets of grid cells, the modelling approach demonstrated to be robust when the learning dataset changes.

The data reported in Table 4 show the statistical significance of the individual predictors that entered the three regression models. The forward stepwise process, which was applied by setting a minimum probability of 0.01 for variable selection at each step, picked 15 attributes in all the three learning environments. Among the 25 analysed physical attributes, 18 entered at least one of the regression models, three were incorporated in only two models and 12 were selected for the three models; the latter 12 consist of all the continuous topographic attributes other than elevation, in addition to south and north-east slope aspects and clay. The Wald test addresses plan curvature and the stream power index as the most significant independent variables for the three samples, followed by clay and profile curvature that are always above 100; the sign and magnitude of $\beta$ coefficients indicate concave (negative curvature) portions of slopes, characterized by high erosive power of runoff (high SPI values) and by the outcropping of clays, as the sectors more frequently affected by gully erosion processes.

The discrimination ability of the logistic regression models is resumed by the classification matrix of Table 5 , in which observed positive and negative cells as well as predicted true/false positive and negative cases are reported together with the results of percent correct for both training and test areas (Märker et al., 2011). For the three samples quite similar accuracy arises for both calibration and validation subsets of cells; models show a slightly higher predictive ability for cells not affected by gullies, compared to cells where gullies occur. Predictive performance of the models was assessed also by means of a cut-off independent technique, based on drawing ROC curves and computing AUC values (Fig. 5a-c). The latter indicate excellent results (cf. Hosmer and Lemeshow, 2000) for all the models both in the training and test subsets of cells; ROC curves are quite similar and, consequently, very small differences of $A U C$ values are observed. Since both the classification matrix and AUC values indicate minor alterations of models as well as predictive power between training and test areas, it can be concluded that the modelling procedure carried out at the grid cell scale has not been suffered from overfitting and the models demonstrated robustness to changes of the learning samples.

\subsection{Slope unit (SLU) models}

Regression analysis carried out on the learning samples of the SLUs $\left(\mathrm{D}_{\mathrm{cal}}, \mathrm{E}_{\mathrm{cal}}\right.$ and $\left.\mathrm{F}_{\mathrm{cal}}\right)$ provided three different susceptibility models. The computed values of the parameters $-2 L L$, pseudo- $R^{2}$ and chi-square (Table 6) indicate that the models fit to the spatial occurrence of gullies in the training subsets with a statistical significance higher than $99 \%$. Nevertheless, compared with the case of CLUs, the goodness of fit of the susceptibility models seems to be less stable when the SLUs' learning samples change. This is confirmed based on the individual predictors that entered the three regression models (Table 7), the forward stepwise

\section{Table 3}

Results of $-2 L L$, model $\chi^{2}$ test and pseudo- $R^{2}$ statistics computed for the regression models calibrated using the learning samples of CLUs. d.f. $=$ degree of freedom.

\begin{tabular}{|c|c|c|c|c|c|c|c|}
\hline \multirow[t]{2}{*}{ Samples } & \multicolumn{2}{|l|}{$-2 L L$} & \multicolumn{3}{|c|}{ Model chi ${ }^{2}$ test (LR) } & \multicolumn{2}{|c|}{ Pseudo- $R^{2}$} \\
\hline & Intercept & Model & $\overline{\chi^{2}}$ & d.f. & $P\left(>\chi^{2}\right)$ & $\begin{array}{l}\text { Cox and } \\
\text { Snell's } R^{2}\end{array}$ & Nagelkerke's $R^{2}$ \\
\hline $\mathrm{A}_{\text {cal }}$ & $19,849.0$ & $14,657.0$ & 5192.0 & 15 & 0.0000 & 0.3041 & 0.4055 \\
\hline $\mathrm{B}_{\mathrm{cal}}$ & $19,849.0$ & $14,683.3$ & 5165.7 & 15 & 0.0000 & 0.3029 & 0.4038 \\
\hline $\mathrm{C}_{\mathrm{cal}}$ & $19,849.0$ & $14,842.8$ & 5006.1 & 15 & 0.0000 & 0.2951 & 0.3934 \\
\hline
\end{tabular}


Table 4

$\beta$ coefficients, Walt test values and their significance computed for the individual predictors that entered the three regression models trained using CLUs.

\begin{tabular}{|c|c|c|c|c|c|c|c|c|c|c|}
\hline \multirow[t]{2}{*}{ Independent variables } & & \multicolumn{3}{|l|}{ Sample A } & \multicolumn{3}{|l|}{ Sample B } & \multicolumn{3}{|l|}{ Sample C } \\
\hline & & $\beta$ coeff. & Wald test & Signif. & $\beta$ coeff. & Wald test & Signif. & $\beta$ coeff. & Wald test & Signif. \\
\hline Clay & LTL_clay & 1.3141 & 147.70 & 0.0000 & 1.2897 & 145.42 & 0.0000 & 1.1846 & 129.37 & 0.0000 \\
\hline Conglomerate & LTL_cong & - & - & - & - & - & - & - & - & - \\
\hline Gypsum & LTL_gyps & - & - & - & - & - & - & - & - & - \\
\hline Sandstone & LTL_sand & - & - & - & - & - & - & - & - & - \\
\hline Arable lands & USE_arab & - & - & - & 0.2368 & 15.70 & 0.0001 & - & - & - \\
\hline Permanent crops & USE_crop & -0.3084 & 16.99 & 0.0000 & - & - & - & -0.4213 & 31.26 & 0.0000 \\
\hline Pastures & USE_past & - & - & - & - & - & - & - & - & - \\
\hline Aspect N & ASP_N & - & - & - & 0.3186 & 18.80 & 0.0000 & 0.2897 & 15.46 & 0.0001 \\
\hline Aspect NE & ASP_NE & 0.4938 & 77.64 & 0.0000 & 0.7038 & 149.10 & 0.0000 & 0.6866 & 141.93 & 0.0000 \\
\hline Aspect E & ASP_E & - & - & - & 0.3317 & 25.24 & 0.0000 & 0.2071 & 10.04 & 0.0015 \\
\hline Aspect SE & ASP_SE & -0.2513 & 14.42 & 0.0001 & - & - & - & - & - & - \\
\hline Aspect S & ASP_S & -0.5180 & 83.19 & 0.0000 & -0.2911 & 25.28 & 0.0000 & -0.4054 & 49.64 & 0.0000 \\
\hline Aspect SW & ASP_SW & - & - & - & - & - & - & - & - & - \\
\hline Aspect W & ASP_W & -0.2997 & 10.59 & 0.0011 & - & - & - & - & - & - \\
\hline Aspect NW & ASP_NW & - & - & - & - & - & - & - & - & - \\
\hline Elevation & ELE & - & - & - & - & - & - & - & - & - \\
\hline SLOPE angle & STP & -5.9556 & 94.51 & 0.0000 & -5.4354 & 78.49 & 0.0000 & -5.8642 & 94.17 & 0.0000 \\
\hline Plan curvature & PLC & -10.6405 & 864.07 & 0.0000 & -10.6499 & 846.98 & 0.0000 & -10.3383 & 824.29 & 0.0000 \\
\hline Profile curvature & PRC & -8.0140 & 130.57 & 0.0000 & -8.4493 & 141.04 & 0.0000 & -8.0181 & 129.76 & 0.0000 \\
\hline Stream power index & SPI & 10.8110 & 792.11 & 0.0000 & 10.2455 & 652.13 & 0.0000 & 10.7386 & 698.14 & 0.0000 \\
\hline Top. wetness Index & TWI & -9.6810 & 111.05 & 0.0000 & -8.8070 & 91.87 & 0.0000 & -10.1823 & 126.99 & 0.0000 \\
\hline LS Factor & LSF & -33.4370 & 110.47 & 0.0000 & -28.6700 & 65.92 & 0.0000 & -31.5047 & 76.75 & 0.0000 \\
\hline Top. position index & TPI & -1.8449 & 97.32 & 0.0000 & -1.7730 & 89.61 & 0.0000 & -1.8125 & 94.04 & 0.0000 \\
\hline Dist. from roads & DFR & 0.6482 & 34.11 & 0.0000 & 0.5599 & 26.06 & 0.0000 & 0.7023 & 41.24 & 0.0000 \\
\hline Flow dist. to river & FDR & -0.5737 & 14.64 & 0.0001 & -0.6769 & 20.27 & 0.0000 & -0.5181 & 11.99 & 0.0005 \\
\hline
\end{tabular}

strategy, which was applied setting a minimum probability of 0.05 for the selection of the variables, picked up two, five and four predictors, of which only two (FDR and ELE) entered at least two models. The maximum flow distance to river, computed within the SLUs, demonstrated to be the best and most significant predictor of the gully occurrence in the training areas, as it is the only attribute included in all the models, in addition to reaching the highest value of the Wald test in the learning samples $\mathrm{D}$ and $\mathrm{F}$.

The classification matrix computed for the SLU regression models (Table 8 ) indicates more enhanced differences of discrimination ability compared with the CLU models. Values of percent correct are quite diverse for the three unit samples and between the learning and validation subsets of the SLUs; moreover, the SLU models demonstrate better accuracy in predicting positive cases than the CLU models.

The performances of the SLU models are acceptable to excellent (cf. Hosmer and Lemeshow, 2000) according to AUC values (Fig. 5d-f). Small differences of predictive skill are observed between the training and test slope units for samples $\mathrm{D}$ and $\mathrm{F}$, while quite diverse AUC values are calculated for sample E of SLUs; these results, together with the classification matrix shown in Table 8, seem to indicate a problem of overfitting only for sample $\mathrm{E}$.

\subsection{Susceptibility maps}

The probability of gully occurrence for all the CLUs and SLUs of the study area was computed by performing further logistic regression analyses. Sample A of CLUs, which provided the highest apparent accuracy, was entirely used as the learning dataset to calculate new regression coefficients; these were transferred to ArcGIS for computing the probability $(P)$ of gully occurrence for all the CLUs. By using the whole basin as the training area, $P$ was calculated also for the SLUs, to generate two gully erosion susceptibility maps with four susceptibility levels (Fig. 6).

The fit of the susceptibility maps with the spatial distribution of gullies was evaluated using ROC curves and AUC values (Fig. 7); both the CLU- and SLU-based gully erosion susceptibility maps show an excellent discriminating ability $(A U C>0.8)$.

Table 5

Observed positive and negative CLUs, predicted true/false positive and negative cases and percent correct for both calibration and validation datasets.

\begin{tabular}{|c|c|c|c|c|c|c|c|c|c|}
\hline \multirow{3}{*}{ Sample } & & \multirow{2}{*}{\multicolumn{2}{|c|}{$\begin{array}{l}\text { Observed cases } \\
\text { Observed cases }\end{array}$}} & \multicolumn{6}{|c|}{ Predicted cases } \\
\hline & & & & \multicolumn{2}{|c|}{ Percent correct } & \multicolumn{2}{|l|}{ Positive } & \multicolumn{2}{|l|}{ Negative } \\
\hline & & Calibration & Validation & Calibration & Validation & Calibration & Validation & Calibration & Validation \\
\hline \multirow[t]{3}{*}{ A } & Positive & 7159 & 1790 & 73.4 & 72.4 & 5254 & 1296 & 1905 & 494 \\
\hline & Negative & 7159 & 1790 & 77.7 & 78.2 & 1596 & 391 & 5563 & 1399 \\
\hline & Sum & 14,318 & 3580 & 75.5 & 75.3 & 6850 & 1687 & 7468 & 1893 \\
\hline \multirow[t]{3}{*}{ B } & Positive & 7159 & 1790 & 73.2 & 72.5 & 5240 & 1297 & 1919 & 493 \\
\hline & Negative & 7159 & 1790 & 77.8 & 76.6 & 1590 & 418 & 5569 & 1372 \\
\hline & Sum & 14,318 & 3580 & 75.5 & 74.6 & 6830 & 1715 & 7488 & 1865 \\
\hline \multirow[t]{3}{*}{ C } & Positive & 7159 & 1790 & 72.6 & 74.7 & 5201 & 1338 & 1958 & 452 \\
\hline & Negative & 7159 & 1790 & 77.9 & 76.6 & 1585 & 419 & 5574 & 1371 \\
\hline & Sum & 14,318 & 3580 & 75.3 & 75.7 & 6786 & 1757 & 7532 & 1823 \\
\hline
\end{tabular}



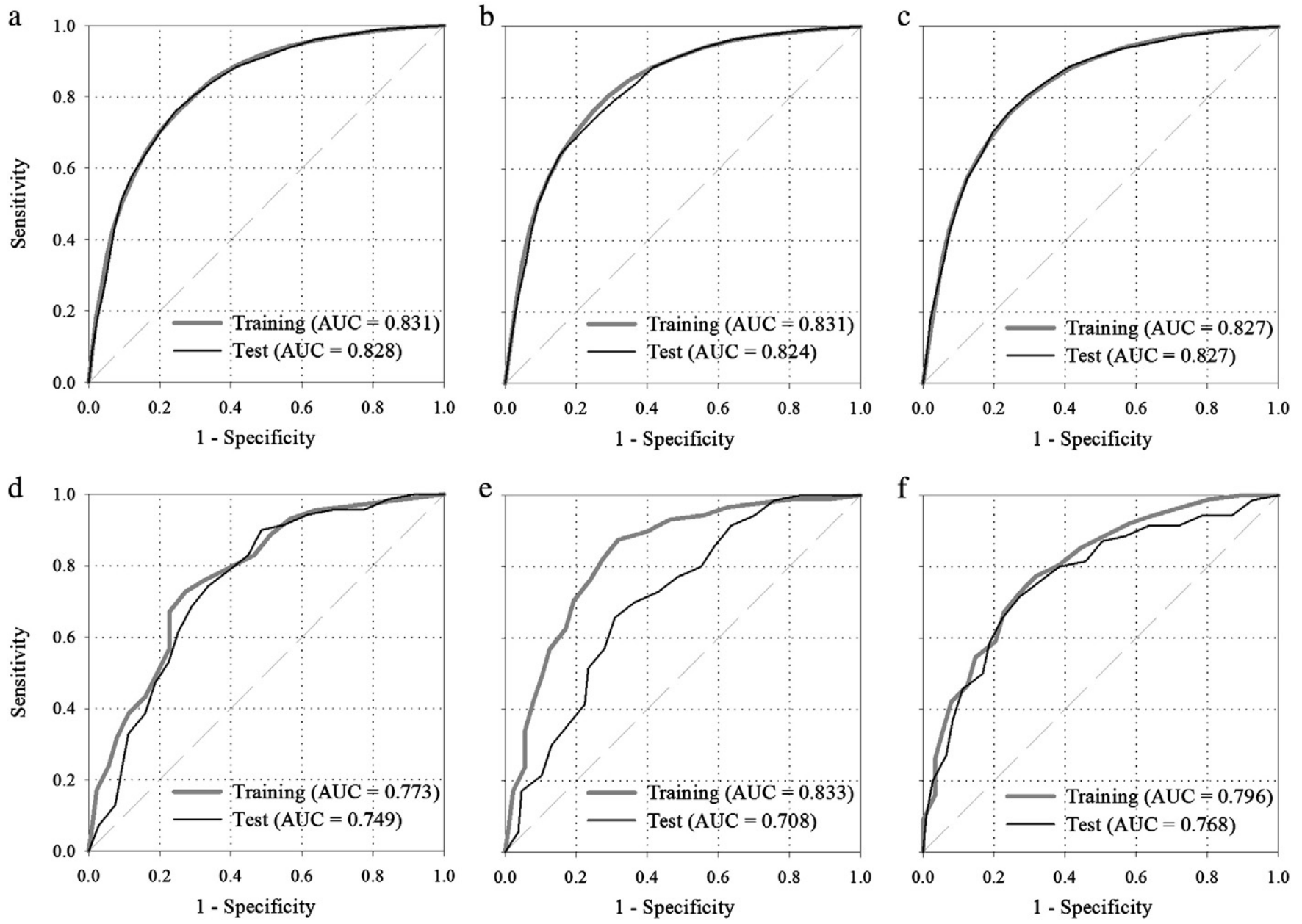

Fig. 5. ROC curves and AUC values of the CLU-based (a-c) and SLU-based (d-f) regression models.

\section{Discussion and conclusion}

The adopted method allowed us to generate gully erosion susceptibility maps that well reflect the spatial distribution of gullies within the study area. The functional relationships between erosion processes and a set of environmental attributes have been assessed by means of forward stepwise logistic regression using three different training samples of the CLUs and SLUs, and the predictive skill of the obtained susceptibility models was tested.

The overall accuracy of the gully erosion susceptibility models, evaluated in terms of ROC curves and AUC values (Fig. 5), is from acceptable to excellent, but some differences arise between the CLU- and SLU-based models when the stability of their performance to change in the learning dataset is addressed. Tables 3 and 6 show that discrimination ability does not suffer from the variation of the training CLUs, whereas regression

Table 6

Results of $-2 L L$, Model $\chi^{2}$ test and pseudo- $R^{2}$ statistics computed for the regression models calibrated using the learning samples of SLUs. d.f $=$ degree of freedom.

\begin{tabular}{|c|c|c|c|c|c|c|c|}
\hline \multirow[t]{2}{*}{ Samples } & \multicolumn{2}{|l|}{$-2 L L$} & \multicolumn{3}{|c|}{ Model $\chi^{2}$ test (LR) } & \multicolumn{2}{|l|}{ Psuedo- $R^{2}$} \\
\hline & Intercept & $\overline{\text { Model }}$ & $\overline{\chi^{2}}$ & d.f. & $P\left(>\chi^{2}\right)$ & $\begin{array}{l}\text { Cox and } \\
\text { Snell's } R^{2}\end{array}$ & $\begin{array}{l}\text { Nagelkerke's } \\
R^{2}\end{array}$ \\
\hline $\mathrm{D}_{\text {cal }}$ & 244.0 & 199.7 & 44.3 & 2 & 0.0000 & 0.2224 & 0.2965 \\
\hline $\mathrm{E}_{\mathrm{cal}}$ & 244.0 & 177.5 & 66.5 & 5 & 0.0000 & 0.3145 & 0.4193 \\
\hline $\mathrm{F}_{\mathrm{cal}}$ & 244.0 & 190.6 & 53.4 & 4 & 0.0000 & 0.2617 & 0.3490 \\
\hline
\end{tabular}

models trained using different learning samples of the SLUs demonstrate variable accuracy. This observation is confirmed from Tables 5 and 8 , where values of percent correct, for both calibration and validation datasets, differ according to the three SLU samples. Moreover, the forward stepwise procedure indicates that the variables selected for the SLU-based susceptibility models are quite different among samples D, E and $\mathrm{F}$. The reduced robustness of the SLU-based models with respect to the CLU-based ones can be explained by the large difference in the number of cases: 353 for the former and 17,898 for the latter. The relationship between the number of training and test SLUs and the stability of the regression models were confirmed when different split percentages of calibration/validation datasets were applied; for example, logistic regression analysis on the SLUs by selecting the same percentage of learning cases $(80 \%)$ provided a more stable fitting $(A U C=0.810,0.798$ and 0.803 ) but enhanced instability of validated accuracy $(A U C=0.731$, 0.819 and 0.763 ) compared to that of the CLUs. Moreover, to test the robustness of the CLU-based models trained using samples of the same size as the SLU samples, we carried out further logistic regression analyses on the three CLU subsets, by randomly selecting 353 cases (158 presences and 195 absences) from each of the three samples of 17,898 CLUs. The results showed the decreased predictive performance and stability of the models for both calibration ( $A U C=0.797,0.847$ and 0.796$)$ and validation $(A U C=0.761,0.803$ and 0.799$)$.

A relatively large number of input variables were used in this research to reproduce the spatial distribution of gullies: 20 topographic attributes and seven variables corresponding to the classes of bedrock lithology and land use. Some spatial correlations are expected between these variables: 
Table 7

$\beta$ coefficients, Walt test values and their significance computed for the individual predictors that entered the three regression models trained using SLUs.

\begin{tabular}{|c|c|c|c|c|c|c|c|c|c|c|}
\hline \multirow[t]{2}{*}{ Independent variables } & & \multicolumn{3}{|l|}{ Sample D } & \multicolumn{3}{|l|}{ Sample E } & \multicolumn{3}{|l|}{ Sample F } \\
\hline & & $\beta$ coeff. & Wald test & Signif. & $\beta$ coeff. & Wald test & Signif. & $\beta$ coeff. & Wald test & Signif. \\
\hline Clay & LTL_clay & - & - & - & - & - & - & 6.3129 & 15.45 & 0.0001 \\
\hline Conglomerate & LTL_cong & - & - & - & - & - & - & - & - & - \\
\hline Gypsum & LTL_gyps & - & - & - & - & - & - & - & - & - \\
\hline Sandstone & LTL_sand & - & - & - & - & - & - & 5.3579 & 6.23 & 0.0126 \\
\hline Arable lands & USE_arab & - & - & - & - & - & - & - & - & - \\
\hline Permanent crops & USE_crop & - & - & - & - & - & - & - & - & - \\
\hline Pastures & USE_past & - & - & - & - & - & - & - & - & - \\
\hline Aspect N & ASP_N & - & - & - & -1.6774 & 3.77 & 0.0523 & - & - & - \\
\hline Aspect NE & ASP_NE & - & - & - & - & - & - & - & - & - \\
\hline Aspect E & ASP_E & - & - & - & - & - & - & - & - & - \\
\hline Aspect SE & ASP_SE & - & - & - & - & - & - & - & - & - \\
\hline Aspect S & ASP_S & - & - & - & - & - & - & - & - & - \\
\hline Aspect SW & ASP_SW & - & - & - & - & - & - & - & - & - \\
\hline Aspect W & ASP_W & - & - & - & - & - & - & - & - & - \\
\hline Aspect NW & ASP_NW & - & - & - & - & - & - & - & - & - \\
\hline Elevation & ELE & -2.5051 & 7.06 & 0.0079 & -2.6645 & 7.50 & 0.0062 & - & - & - \\
\hline Elevation range & ELR & - & - & - & - & - & - & - & - & - \\
\hline Slope angle & STP & - & - & - & -14.6399 & 15.73 & 0.0001 & - & - & - \\
\hline Plan curvature & PLC & - & - & - & - & - & - & - & - & - \\
\hline Profile curvature & PRC & - & - & - & - & - & - & -4.2397 & 6.59 & 0.0103 \\
\hline Stream power index & SPI & - & - & - & - & - & - & - & - & - \\
\hline Top. wetness Index & TWI & - & - & - & -15.8756 & 18.59 & 0.0000 & - & - & - \\
\hline LS Factor & LSF & - & - & - & - & - & - & - & - & - \\
\hline Top. position index & TPI & - & - & - & - & - & - & - & - & - \\
\hline Road network length & RNL & - & - & - & - & - & - & - & - & - \\
\hline Flow dist. to river & FDR & 5.8784 & 32.18 & 0.0000 & 5.0714 & 18.22 & 0.0000 & 4.8043 & 19.41 & 0.0000 \\
\hline
\end{tabular}

for example, lithology controls topography that in turn can influence land use; moreover, four of the topographic variables are secondary computed by combining other topographic variables. However, because of the individual implications of the input variables and the robustness of logistic regression against auto-correlations (Mathew et al., 2009), we submitted all the environmental attributes in Table 2 to the forward stepwise procedure for building the models.

Tables 4 and 7 show the values of the $\beta$ coefficient and the significance of the independent variables that were selected by the forward stepwise analysis, carried out on the CLUs and SLUs, respectively. These tables indicate that continuous topographic attributes more frequently contribute to the regression models particularly for the CLU-based models for which all continuous topographic variables except for elevation are always selected because of their high significance. This agrees with De Oliveira (1990) and Meyer and MartínezCasasnovas (1999) in that gully distribution is mainly determined by topographic factors. The $\beta$ coefficients of curvature and the stream power index demonstrate how gully erosion intensity increases with runoff volume and convergence. However, our study also points to important relationships between gully occurrence and clay lithology in relation to mechanical resistance to erosion.
The excellent predictive performance of both the CLU- and SLU-based models (Fig. 7) confirmed that logistic regression is an effective tool for erosion susceptibility analysis. Moreover, the results of the accuracy tests demonstrated the reliability of the susceptibility maps from the objective and reproducible procedures.

This research also highlights that the SLUs can be adopted as elementary sample units for analysing gully erosion susceptibility, even if further investigation is needed to improve the predictive performance and robustness of the models. The use of such mapping units may overcome the intrinsic limits of purely statistical approaches to a geomorphological issue. A cell unit approach, even with neighbourhood statistics, does not take into account the landscape and hydrological connectivity between pixels (Bracken and Croke, 2007). In this sense, the SLUs could provide a better terrain partitioning since their boundaries coincide with natural limits of runoff. However, the adoption of the SLUs may reduce the resolution of topography, when a single attribute value is assigned to each spatial unit. These values are more concentrated around their mean compared to those assigned to the CLUs (Table 2), suggesting a loss of information and a potential worsening of the predictive skill of the models. This problem may be solved by reducing the size of the SLUs.

Table 8

Observed positive and negative SLUs, predicted true/false positive and negative cases and percent correct for both calibration and validation datasets.

\begin{tabular}{|c|c|c|c|c|c|c|c|c|c|}
\hline \multirow{3}{*}{ Sample } & & \multirow{2}{*}{\multicolumn{2}{|c|}{$\begin{array}{l}\text { Observed cases } \\
\text { Observed cases }\end{array}$}} & \multicolumn{6}{|c|}{ Predicted cases } \\
\hline & & & & \multicolumn{2}{|c|}{ Percent correct } & \multicolumn{2}{|l|}{ Positive } & \multicolumn{2}{|l|}{ Negative } \\
\hline & & Calibration & Validation & Calibration & Validation & Calibration & Validation & Calibration & Validation \\
\hline \multirow[t]{3}{*}{ D } & Positive & 88 & 70 & 73.9 & 71.4 & 65 & 50 & 23 & 20 \\
\hline & Negative & 88 & 107 & 71.6 & 70.1 & 25 & 32 & 63 & 75 \\
\hline & Sum & 176 & 177 & 72.7 & 70.6 & 90 & 82 & 86 & 95 \\
\hline \multirow[t]{3}{*}{ E } & Positive & 88 & 70 & 76.1 & 71.4 & 67 & 50 & 21 & 20 \\
\hline & Negative & 88 & 107 & 72.7 & 60.7 & 24 & 42 & 64 & 65 \\
\hline & Sum & 176 & 177 & 74.4 & 65.0 & 91 & 92 & 85 & 85 \\
\hline \multirow[t]{3}{*}{$\mathrm{F}$} & Positive & 88 & 70 & 75.0 & 77.1 & 66 & 54 & 22 & 16 \\
\hline & Negative & 88 & 107 & 72.7 & 64.5 & 24 & 38 & 64 & 69 \\
\hline & Sum & 176 & 177 & 73.9 & 69.5 & 90 & 92 & 86 & 85 \\
\hline
\end{tabular}




\section{Susceptibility levels}

low $[0<\mathrm{P}<0.25]$

moderate $[0.25<\mathrm{P}<0.5]$

high $[0.5<\mathrm{P}<0.75]$

very high $[0.75<\mathrm{P}<1]$
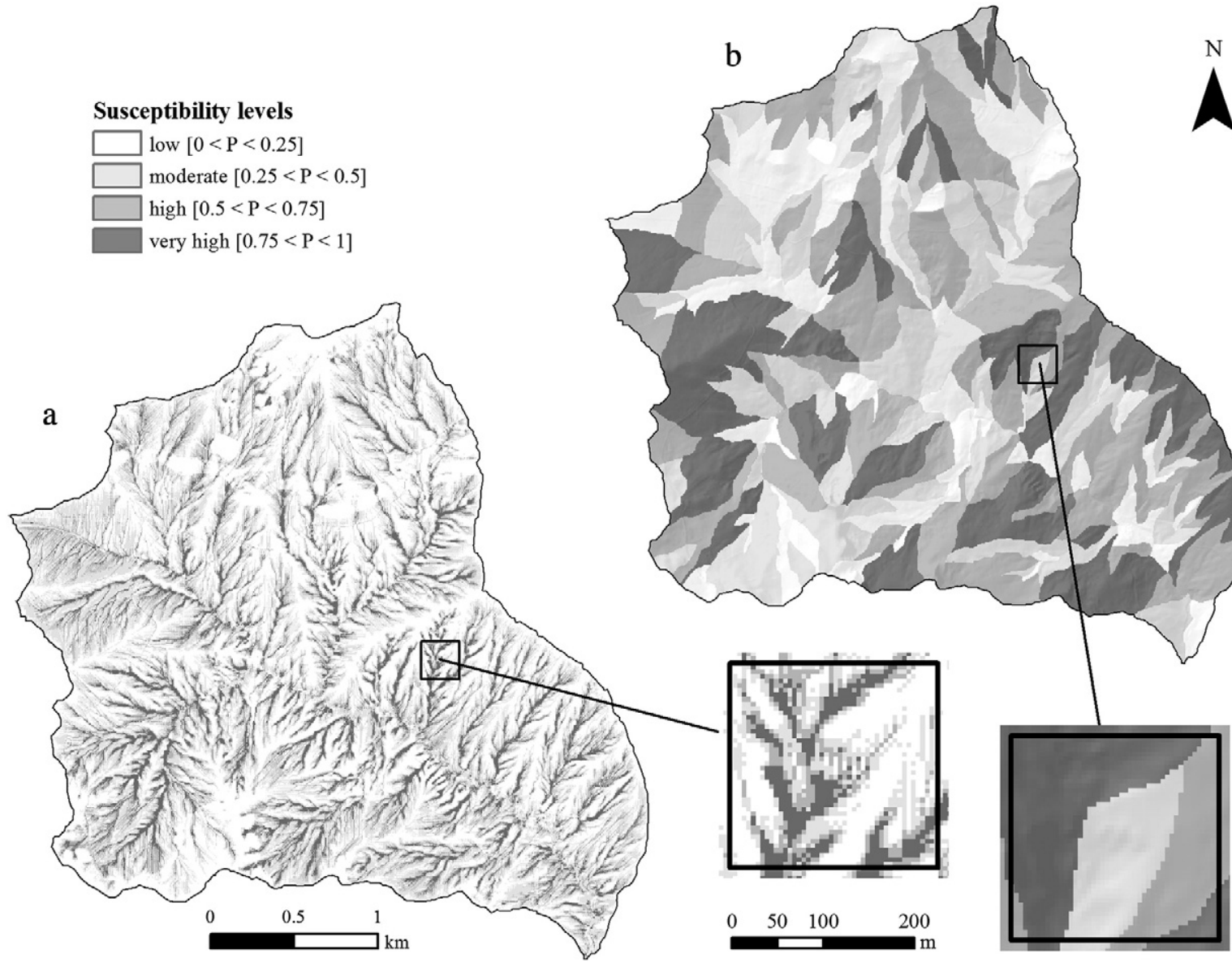

$\ddot{1}$

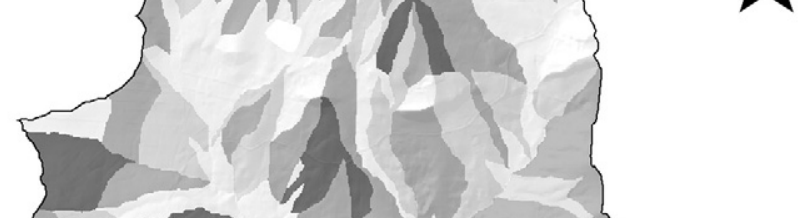

Fig. 6. CLU-based (a) and SLU-based (b) gully erosion susceptibility maps.

In conclusion, our study on the basin of the San Giorgio River has shown that topographic attributes mainly control gully erosion and thus determine the spatial distribution of gullies. Moreover, logistic regression is found to be suitable for preparing reliable gully erosion susceptibility maps. In addition, cell-based models have a higher accuracy and robustness than those based on slope units. However, the latter also have provided acceptable predictive skills, and it seems possible to increase their performance if their drawbacks related to the loss of topography are reduced.

\section{Acknowledgements}

This study was carried out in the framework of two projects: i) the project PRIN 2007 "EROMED”, funded by the Italian Ministry of Education, University and Research, coordinated by Dr. Michael Märker; and ii) the project VIGONI 2009 "Soil erosion assessment in the Mediterranean: An integrative approach combining field studies, remote sensing methods and process based modelling in the Imera Catchment of Northern Sicily, Italy", funded by the German-Italian University Center, coordinated by

b



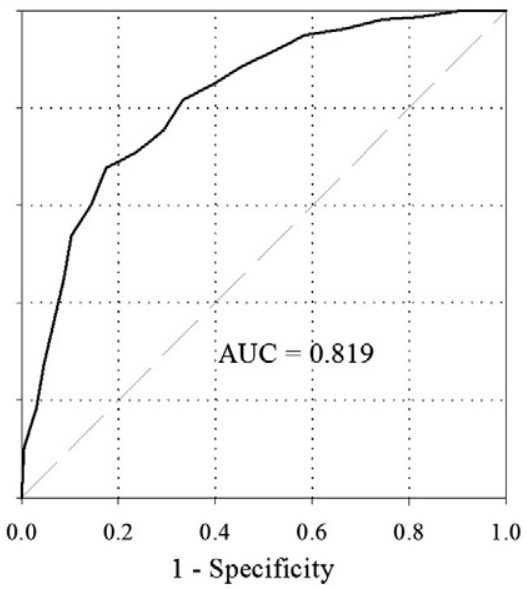

Fig. 7. ROC curves and AUC values of the CLU-based (a) and SLU-based (b) gully erosion susceptibility maps. 
Dr. Christian Conoscenti, for the Italian side, and Prof. Volker Hoschild, for the German side.

The authors wish to thank the two anonymous reviewers and the editor Prof. T. Oguchi for their useful comments and suggestions, and Clare Hampton for the linguistic editing of the text.

\section{References}

Abate, B., Renda, P., Tramutoli, M., 1988. Carta Geologica dei Monti di Termini Imerese e delle Madonie occidentali (Sicilia Centro-settentrionale), scala 1: 50000. Dipartimento di Scienze della Terra e del Mare (DiSTeM) dell'Università di Palermo. Stab.Tip. Salomone, Roma.

Akgün, A., Türk, N., 2011. Mapping erosion susceptibility by a multivariate statistical method: a case study from the Ayvalık region, NW Turkey. Comput. Geosci. 37, 1515-1524.

Baeza, C., Lantada, N., Moya, J., 2009. Influence of sample and terrain unit on landslide susceptibility assessment at La Pobla de Lillet, Eastern Pyrenees, Spain. Environ. Earth Sci. 60, 155-167.

Bai, S.-B., Wang, J., Lü, G.-N., Zhou, P.-G., Hou, S.-S., Xu, S.-N., 2010. GIS-based logistic regression for landslide susceptibility mapping of the Zhongxian segment in the Three Gorges area, China. Geomorphology 115, 23-31.

Bocco, G., 1991. Gully erosion: processes and models. Prog. Phys. Geogr. 15, 392-406.

Bou Kheir, R., Wilson, J., Deng, Y., 2007. Use of terrain variables for mapping gully erosion susceptibility in Lebanon. Earth Surf. Process. Landforms 32, 1770-1782.

Bracken, L.J., Croke, J., 2007. The concept of hydrological connectivity and its contribution to understanding runoff-dominated geomorphic systems. Hydrol. Process. 21, 1749-1763.

Bruno, C., Di Stefano, C., Ferro, V., 2008. Field investigation on rilling in the experimental Sparacia area, South Italy. Earth Surf. Process. Landforms 33, 263-279.

Bryan, R.B., Jones, J.A.A., 2000. The significance of soil piping processes, inventory and prospect. Geomorphology 20, 209-218.

Bull, L.J., Kirkby, M.J., 1997. Gully processes and modelling. Prog. Phys. Geogr. 21, 354-374.

Capra, A., Mazzara, L.M., Scicolone, B., 2005. Application of the EGEM model to predict ephemeral gully erosion in Sicily, Italy. Catena 59, 133-146.

Capra, A., Di Stefano, C., Ferro, V., Scicolone, B., 2009. Similarity between morphological characteristics of rills and ephemeral gullies in Sicily, Italy. Hydrol. Process. 3341, 3334-3341.

Capra, A., Ferro, V., Porto, P., Scicolone, B., 2012. Quantifying interrill and ephemeral gully erosion in a small Sicilian basin. Z. Geomorphol., Suppl. Issues 56, 9-25.

Caraballo-Arias, N.A., Conoscenti, C., Di Stefano, C., Ferro, V., 2013. Testing GIS-morphometric analysis of some Sicilian badlands. Catena. http://dx.doi.org/10.1016/j.catena. 2013.08.021.

Carrara, A., Cardinali, M., Guzzetti, F., Reichenbach, P., 1995. GIS technology in mapping landslide hazard. In: Carrara, A., Guzzetti, F. (Eds.), Geographical Information Systems in Assessing Natural Hazards. Kluwer, Dordrecht, pp. 135-175.

Castillo, V.M., Gómez-Plaza, A., Martínez-Mena, M., 2003. The role of antecedent soil water content in the runoff response of semiarid catchments: a simulation approach. J. Hydrol. 284, 114-130.

Chaplot, V., 2013. Impact of terrain attributes, parent material and soil types on gully erosion. Geomorphology 186, 1-11.

Chaplot, V., Coadou le Brozec, E., Silvera, N., Valentin, C., 2005. Spatial and temporal assessment of linear erosion in catchments under sloping lands of northern Laos. Catena 63, 167-184.

Conforti, M., Aucelli, P.P.C., Robustelli, G., Scarciglia, F., 2010. Geomorphology and GIS analysis for mapping gully erosion susceptibility in the Turbolo stream catchment (Northern Calabria, Italy). Nat. Hazard. 56, 881-898.

Conoscenti, C., Di Maggio, C., Rotigliano, E., 2008. Soil erosion susceptibility assessment and validation using a geostatistical multivariate approach: a test in Southern Sicily. Nat. Hazard. 46, 287-305.

Conoscenti, C., Agnesi, V., Angileri, S., Cappadonia, C., Rotigliano, E., Märker, M., 2013. A GIS-based approach for gully erosion susceptibility modelling: a test in Sicily, Italy. Environ. Earth Sci. http://dx.doi.org/10.1007/s12665-012-2205-y.

De Oliveira, M.A.T., 1990. Slope geometry and gully erosion development: Bananal, São Paulo, Brazil. Z. Geomorphol. N. F. 34 (4), 423-434.

Descroix, L., Nouvelot, J.F., Vauclin, M., 2002. Evaluation of an antecedent precipitation index to model runoff yield in the western Sierra Madre (North-West Mexico). J. Hydrol. 263, 114-130.

Desmet, P.J.J., Poesen, J., Govers, G., Vandaele, K., 1999. Importance of slope gradient and contributing area for optimal prediction of the initiation and trajectory of ephemeral gullies. Catena 37, 377-392.

Di Stefano, C., Ferro, V., 2011. Measurements of rill and gully erosion in Sicily. Hydrol. Process. 25, 2221-2227.

El Maaoui, M.A., Sfar Felfoul, M., Boussema, M.R., Snane, M.H., 2012. Sediment yield from irregularly shaped gullies located on the Fortuna lithologic formation in semi-arid area of Tunisia. Catena 93, 97-104.

ESRI, 2008. ArcGIS Version 9.3. ESRI, Redlands CA, USA.

Fawcett, T., 2006. An introduction to ROC analysis. Pattern Recognit. Lett. 27, 861-874.

Fierotti, G., 1988. Carta dei Suoli della Sicilia. Ist. di Agronomia, Univ. di Palermo e Regione Sicilia, Assessorato Territorio e Ambiente, Palermo, Italy.

Flanagan, D.C., Nearing, M.A., 1995. USDA-Water Erosion Prediction Project: hillslope profile and watershed model documentation. NSERL Report \#10.USDA-ARS National Soil Erosion Research Laboratory, West Lafayette, Indiana.

Foster, G.R., 1986. Understanding ephemeral gully erosion. Soil Conservation. , vol. 2. National Academy of Science Press, Washington, DC, pp. 90-125.
Geissen, V., Kampichler, C., López-de Llergo-Juárez, J.J., Galindo-Acántara, A., 2007. Superficial and subterranean soil erosion in Tabasco, tropical Mexico: development of a decision tree modeling approach. Geoderma 139, 277-287.

Gómez Gutiérrez, Á., Schnabel, S., Felicísimo, Á.M., 2009a. Modelling the occurrence of gullies in rangelands of southwest Spain. Earth Surf. Process. Landforms 34, 1894-1902.

Gómez Gutiérrez, Á., Schnabel, S., Lavado Contador, F., 2009b. Gully erosion, land use and topographical thresholds during the last 60 years in a small rangeland catchment in SW Spain. Land Degrad. Dev. 20, 535-550.

Gómez Gutiérrez, Á., Schnabel, S., Lavado Contador, F., 2009c. Using and comparing two nonparametric methods (CART and MARS) to model the potential distribution of gullies. Ecol. Model. 220, 3630-3637.

Gómez Gutiérrez, Á., Schnabel, S., Lavado Contador, F., 2011. Procesos, factores y consecuencias de la erosión por cárcavas; trabajos desarrollados en la Península Ibérica. Bol. Asoc. Geógr. Esp. 55, 59-80.

Guzzetti, F., Carrara, Alberto, Cardinali, Mauro, Reichenbach, Paola, 1999. Landslide hazard evaluation: a review of current techniques and their application in a multi-scale study, Central Italy. Geomorphology 31, 181-216.

Hanley, J.A., McNeil, B.J., 1982. The meaning and use of the area under a receiver operating characteristic (ROC) curve. Radiology 143, 29-36.

Hauge, C., 1977. Soil erosion definitions. Calif. Geol. 30, 202-203.

Hosmer, D.W., Lemeshow, S., 2000. Applied Logistic Regression, Wiley Series in Probability and Statistics. Wiley.

Hughes, A.O., Prosser, I.P., Stevenson, J., Scott, A., Lu, H., Gallant, J., Moran, C.J., 2001. Gully Erosion Mapping for the National Land and Water Resources Audit. CSIRO Land and Water Technical report.

Imeson, A.C., Kwaad, F.J.P.M., 1980. Gully types and gully prediction. Geogr. Tijdschr. 14, 430-441.

Ireland, H.A., Sharpe, C.F.S., Eargle, D.H., 1939. Principles of gully erosion in the Piedmont of South Carolina. USDA Technol. Bull. 633.

Jenness, J., 2006. Topographic Position Index (tpi_jen.avx) Extension for ArcView 3.x. Jenness Enterprises.

Jungerius, P.D., Matundura, J., Van de Ancker, J.a.M., 2002. Road construction and gully erosion in West Pokot, Kenya. Earth Surf. Process. Landforms 27, 1237-1247.

Kakembo, V., Xanga, W.W., Rowntree, K., 2009. Topographic thresholds in gully development on the hillslopes of communal areas in Ngqushwa Local Municipality, Eastern Cape, South Africa. Geomorphology 110, 188-194.

Kirkby, M.J., Bracken, L.J., 2009. Gully processes and gully dynamics. Earth Surf. Process. Landforms 1851, 1841-1851.

Knisel, W.G., 1980. CREAMS: a field scale model for chemicals, runoff and erosion from agricultural management systems. US Department of Agriculture. Conserv. Res. Rep. 26 474-485.

Kompani-Zare, M., Soufi, M., Hamzehzarghani, H., Dehghani, M., 2011. The effect of some watershed, soil characteristics and morphometric factors on the relationship between the gully volume and length in Fars Province, Iran. Catena 86, 150-159.

Laflen, J.M., Watson, D.A., Franti, T.G., 1986. Ephemeral gully erosion. Proceedings of the Fourth Federal Interagency Sedimentation Conference. Las Vegas, NV, pp. 329-337.

Lasko, T.A., Bhagwat, J.G., Zou, K.H., Ohno-Machado, L., 2005. The use of receiver operating characteristic curves in biomedical informatics. J. Biomed. Inform. 38, 404-415.

Li, Y., Poesen, J., Yang, J.C., Fu, B., Zhang, J.H., 2003. Evaluating gully erosion using 137Cs and $210 \mathrm{~Pb} / 137 \mathrm{Cs}$ ratio in a reservoir catchment. Soil Tillage Res. 69, 107-115.

Lucà, F., Conforti, M., Robustelli, G., 2011. Comparison of GIS-based gullying susceptibility mapping using bivariate and multivariate statistics: Northern Calabria, South Italy Geomorphology 134, 297-308.

Magliulo, P., 2010. Soil erosion susceptibility maps of the Janare Torrent Basin (Southern Italy). J. Maps 6, 435-447.

Magliulo, P., 2012. Assessing the susceptibility to water-induced soil erosion using a geomorphological, bivariate statistics-based approach. Environ. Earth Sci. 67, 1801-1820.

Märker, M., Pelacani, S., Schröder, B., 2011. A functional entity approach to predict soil erosion processes in a small Plio-Pleistocene Mediterranean catchment in Northern Chianti, Italy. Geomorphology 125, 530-540.

Martínez-Casasnovas, J.A., Ramos, M.C., Poesen, J., 2004. Assessment of sidewall erosion in large gullies using multi-temporal DEMs and logistic regression analysis. Geomorphology 58, 305-321.

Marzolff, I., Ries, J.B., Poesen, J., 2011. Short-term versus medium-term monitoring for detecting gully-erosion variability in a Mediterranean environment. Earth Surf. Process. Landforms 36, 1604-1623.

Mathew, J., Jha, V.K., Rawat, G.S., 2009. Landslide susceptibility zonation mapping and its validation in part of Garhwal Lesser Himalaya, India, using binary logistic regression analysis and receiver operating characteristic curve method. Landslides 6, 17-26.

Meijerink, A.M.J., 1988. Data acquisition and data capture through terrain mapping units. ITC J. 1, 23-44.

Menard, S., 1995. Applied Logistic Regression Analysis, Online. Sage Publications.

Merkel, W.H., Woodward, D.E., Clarke, C.D., 1988. Ephemeral gully erosion mode (EGEM). Agricultural, Forest, and Rangeland Hydrology. , 07-88. American Society of Agricultural Engineers Publication 315-323.

Meyer, A., Martínez-Casasnovas, J.A., 1999. Prediction of existing gully erosion in vineyard parcels of the NE Spain: a logistic modelling approach. Soil Tillage Res. 50, 319-331.

Montgomery, D.R., Dietrich, W.E., 1992. Channel initiation and the problem of landscape scale. Science 255, 826-830.

Moore, I.D., Burch, G.J., Mackenzie, D.H., 1988. Topographic effects on the distribution of surface soil water and the location of ephemeral gullies. Trans. ASAE 32 (32), 1098-1107.

Moretti, S., Rodolfi, G., 2000. A typical "calanchi” landscape on the Eastern Apennine margin (Atri, Central Italy): geomorphological features and evolution. Catena 40, 217-228.

Nachtergaele, J., Poesen, J., Vandekerckhove, L., Oostwoud Wijdenes, D., Roxo, M., 2001a. Testing the Ephemeral Gully Erosion Model (EGEM) in Mediterranean environments. 
In: Stott, D.E., Mohtar, R.H., Steinhardt, G.C. (Eds.), Sustaining the Global Farm Selected Papers from the 10th International Soil Conservation Organization Meeting, May 24-29, 1999, West Lafayette, IN, pp. 1024-1028.

Nachtergaele, J., Poesen, J., Vandekerckhove, L., Oostwoud Wijdenes, D., Roxo, M., 2001b. Testing the ephemeral gully erosion model (EGEM) for two Mediterranean environments. Earth Surf. Process. Landforms 26, 17-30.

Nachtergaele, J., Poesen, J., Sidorchuk, A., Torri, D., 2002. Prediction of concentrated flow width in ephemeral gully channels. Hydrol. Process. 16, 1935-1953.

Nazari Samani, A., Ahmadi, H., Jafari, M., Boggs, G., Ghoddousi, J., Malekian, A., 2009. Geomorphic threshold conditions for gully erosion in Southwestern Iran (BoushehrSamal watershed). J. Asian Earth Sci. 35, 180-189.

Nefeslioglu, H., Gokceoglu, C., Sonmez, H., 2008. An assessment on the use of logistic regression and artificial neural networks with different sampling strategies for the preparation of landslide susceptibility maps. Eng. Geol. 97, 171-191.

Nyssen, J., Poesen, J., Moeyersons, J., Luyten, E., Veyret-Picot, M., Deckers, J., Haile, M., Govers, G., 2002. Impact of road building on gully erosion risk: a case study from the Northern Ethiopian Highlands. Earth Surf. Process. Landforms $27,1267-1283$.

Nyssen, J., Poesen, J., Moeyersons, J., Haile, M., Deckers, J., 2008. Dynamics of soil erosion rates and controlling factors in the Northern Ethiopian Highlands - towards a sediment budget. Earth Surf. Process. Landforms 33, 695-711.

Ohlmacher, G.C., Davis, J.C., 2003. Using multiple logistic regression and GIS technology to predict landslide hazard in northeast Kansas, USA. Eng. Geol. 69, 331-343.

Olaya, V., 2004. A Gentle Introduction to SAGA GIS. Göettingen, Germany.

Patton, P.C., Schumm, S.A., 1975. Gully erosion, northwestern Colorado: a threshold phenomenon. Geology 31, 187-199.

Phillips, C.P., 1998. The badlands of Italy: a vanishing landscape? Applied Geography 18 (3), 243-257.

Poesen, J., 1993. Gully typology and gully control measures in the European loess belt. In: Wicherek, S. (Ed.), Farm Land Erosion in Temperate Plains Environment and Hills. Elsevier, Amsterdam, pp. 221-239.

Poesen, J., Vandaele, K., Van Wesemael, B., 1996. Contribution of gully erosion to sediment production on cultivated lands and rangelands. , 236. IAHS Publications 251-266.

Poesen, J. Vandekerckhove, L, Nachtergaele, J. Oostwoud Wijdenes, D., Verstraeten, G Van Wesemael, B., 2002. Gully erosion in dryland environments. In: Bull, L.J. Kirkby, M.J. (Eds.), Dryland Rivers: Hydrology and Geomorphology of Semi-arid Channels. Wiley \& Sons, Chichester, England, pp. 229-262.

Poesen, J., Nachtergaele, J., Verstraeten, G., Valentin, C., 2003. Gully erosion and environmental change: importance and research needs. Catena 50, 91-133.

Pulice, I., Cappadonia, C., Scarciglia, Fabio, Robustelli, Gaetano, Conoscenti, C., De Rose, R., Rotigliano, E., Agnesi, V., 2012. Geomorphological, chemical and physical study of "calanchi" landforms in NW Sicily (southern Italy). Geomorphology 153-154, 219-231.

Rakotomalala, R., 2005. Tanagra: un logiciel gratuit pour l'enseignement et la recherche. Actes De EGC, pp. 697-702.

Ripley, B.D., 1996. Pattern Recognition and Neural Networks, Analysis. Cambridge University Press, Cambridge.
Rotigliano, E., Agnesi, V., Cappadonia, C., Conoscenti, C., 2011. The role of the diagnostic areas in the assessment of landslide susceptibility models: a test in the Sicilian chain. Nat. Hazard. 58, 981-999.

Rotigliano, E., Cappadonia, C., Conoscenti, C., Costanzo, D., Agnesi, V., 2012. Slope unitsbased flow susceptibility model: using validation tests to select controlling factors. Nat. Hazard. 61, 143-153.

Sidorchuk, A., 1999. Dynamic and static models of gully erosion. Catena 37, 401-414.

Svoray, T., Markovitch, H., 2009. Catchment scale analysis of the effect of topography, tillage direction and unpaved roads on ephemeral gully incision. Earth Surf. Process. Landforms 34, 1970-1984.

Svoray, T., Michailov, E., Cohen, A., Rokah, L., Sturm, A., 2012. Predicting gully initiation: comparing data mining techniques, analytical hierarchy processes and the topographic threshold. Earth Surf. Process. Landforms 37, 607-619.

Takken, I., Croke, J., Lane, P., 2008. Thresholds for channel initiation at road drain outlets. Catena 75, 257-267.

Torri, D., Poesen, J., Borselli, L., Knapen, A., 2006. Channel width-flow discharge relationships for rills and gullies. Geomorphology 76, 273-279.

Torri, D., Poesen, J., Borselli, L., Bryan, R., Rossi, M., 2012a. Spatial variation of bed roughness in eroding rills and gullies. Catena 90, 76-86.

Torri, D., Borselli, L., Gariano, S.L., Greco, R., Iaquinta, P., Iovine, G., Poesen, J., Terranova, O.G., 2012b. Identifying gullies in the Mediterranean environment by coupling a complex threshold model and a GIS. Rend. Online Soc. Geol. Ital. 21, 441-443.

UNEP, 1994. United Nations Convention to Combat Desertification. United Nations Environmental Programme, Geneva.

USDA-SCS, 1966. Procedure for determining rates of land damage, land depreciation, and volume of sediment produced by gully erosion. Technical Release No. 32. US GPO 1990-261-419:20727/SCS.US Government Printing Office, Washington, DC.

Valcárcel, M., Taboada, M.T., Paz, A., Dafonte, J., 2003. Ephemeral gully erosion in northwestern Spain. Catena 50, 199-216.

Valentin, C., Poesen, J., Li, Y., 2005. Gully erosion: impacts, factors and control. Catena 63, $132-153$.

Vandekerckhove, L., Poesen, J., Oostwoud Wijdenes, D., De Figueiredo, T., 1998. Topographical thresholds for ephemeral gully initiation in intensively cultivated areas of the Mediterranean. Catena 33, 271-292.

Vandekerckhove, L., Poesen, J., Oostwoud Wijdenes, D., Gyssels, G., Beuselinck, L., De Luna, E., 2000a. Characteristics and controlling factors of bank gullies in two semi-arid Mediterranean environments. Geomorphology 33, 37-58.

Vandekerckhove, L., Poesen, J., Oostwoud Wijdenes, D., Nachtergaele, J., Kosmas, C., Roxo, M.J., De Figueiredo, T., 2000b. Thresholds for gully initiation and sedimentation in Mediterranean Europe. Earth Surf. Process. Landforms 25, 1201-1220.

Weiss, A., 2001. Topographic position and landforms analysis. Poster Presentation, ESRI User Conference, San Diego, CA.

Wilson, J.P., Gallant, J.C., 2000. Terrain Analysis: Principles and Applications. Wiley \& Sons, Inc., Chichester:

Woodward, D.E., 1999. Method to predict cropland ephemeral gully erosion. Catena 37, 393-399.

Zucca, C., Canu, A., Della Peruta, R., 2006. Effects of land use and landscape on spatial distribution and morphological features of gullies in an agropastoral area in Sardinia (Italy). Catena 68, 87-95. 